University of Pretoria etd - Ramchander, P (2004)

\title{
TOWARDS THE RESPONSIBLE MANAGEMENT OF THE SOCIO-CULTURAL IMPACT OF TOWNSHIP TOURISM
}

by

PRANILL RAMCHANDER

Submitted in partial fulfillment of the requirements for the degree of Philosophiae Doctor in the Faculty of Economic and Manageme nt Sciences,

University of Pretoria

Department of Tourism Management

April 2004 


\section{CHAPTER 1: GENERAL ORIENTATION OF THE STUDY}

\subsection{INTRODUCTION}

1.2 SOCIAL AND CULTURAL IMPACT OF TOURISM ON THE HOST COMMUNITY

1.3 SOUTH AFRICA'S CULTURAL RESOURCES POST 1994

1.4 TOWNSHIP TOURISM 6

1.5 FORMULATION OF RESEARCH PROBLEM 10

$\begin{array}{ll}\text { 1.5.1 Problem Statement } & 11\end{array}$

1.6 REASONS FOR SELECTING SOWETO AS THE STUDY AREA 12

$\begin{array}{lll}1.7 & \text { AIM AND OBJECTIVES OF THE STUDY } & 14\end{array}$

$\begin{array}{lll}1.8 & \text { VALUE OF THE RESEARCH } & 15\end{array}$

$\begin{array}{lll}1.9 & \text { ASSUMPTIONS } & 17\end{array}$

$\begin{array}{ll}1.10 \text { DELIMITATIONS } & 17\end{array}$

$\begin{array}{lll}1.11 & \text { RESEARCH PHILOSOPHY } & 18\end{array}$

1.11.1 Dimensions of tourism management 19

1.11.2 Philosophy of research methodology 20

$\begin{array}{ll}1.12 \text { METHODOLOGY } & 20\end{array}$

$\begin{array}{ll}1.13 \text { RESEARCH DESIGN } & 21\end{array}$

1.14 DEFINITION OF KEY CONCEPTS 23

1.15 ORGANISATION OF CHAPTERS 23

$\begin{array}{ll}1.16 \text { SUMMARY } & 25\end{array}$ 


\section{CHAPTER 2: BACKGROUND TO THE STUDY AREA: SOWETO}

2.1 INTRODUCTION 26

2.2 DEVELOPMENT OF SOWETO SOCIETY 26

2.2.1 Soweto and the 1976 uprising 28

2.2.2 The road to democracy 29

$\begin{array}{ll}\text { 2.2.3 Population profile and culture } & 29\end{array}$

$\begin{array}{lll}2.3 & \text { RELIGION } & 33\end{array}$

2.4 SPAZA SHOPS 34

2.5 TRANSPORT 34

$\begin{array}{lll}2.6 & \text { SPORT } & 35\end{array}$

$\begin{array}{lll}2.7 & \text { POLITICAL PARTIES } & 41\end{array}$

2.8 INDUSTRIAL ACTIVITY 41

2.9 A BRIEF HISTORY OF BLACK EDUCATION 41

2.10 HOUSING 43

2.11 HEALTH CARE AND CHRIS HANI BARAGWANATH HOSPITAL 45

2.12 THE SOWETO TOWNSHIP TOURISM TRAIL 46

2.13 THE DEMAND FOR TOWNSHIP TOURISM 48

2.14 TOURIST EXPECTATIONS OF TOWNSHIP EXPERIENCES 51

2.15 SUMMARY 53

CHAPTER 3: LITERATURE REVIEW: PERCEPTIONS OF SOCIOCULTURAL IMPACTS AND THEORETICAL FRAMEWORK

3.1 INTRODUCTION 53

3.2 SPECIAL-INTEREST TOURISM AND CULTURAL TOURISM 53 MOTIVATORS

3.3 FACTORS FACILITATING THE GROWTH OF CULTURAL TOURISM 56

3.4 IN SEARCH OF AUTHENTICITY — A CULTURAL TOURIST MOTIVATION DEBATE 
3.5 THE RELATIONSHIP BETWEEN HOST AND GUEST

3.6 CHARACTERISTICS OF HOST-GUEST RELATIONSHIPS: KEY TO SUCCESS OR DISASTER?

3.7 HOST PERCEPTIONS OF IMPACTS AND THE NEED FOR HOST PERCEPTION RESEARCH

3.8 SYNOPSIS OF THE LITERATURE DEALING WITH THE PERCEIVED POSITIVE AND NEGATIVE SOCIO-CULTURAL IMPACTS OF TOURISM DEVELOPMENT

3.9 A TYPOLOGY OF TOURISM-HOST COMMUNITY RELATIONSHIPS 69

3.10 TOURIST-HOST CONTACT IN LESS DEVELOPED COUNTRIES 71

3.11 DETERMINANTS OF HOST COMMUNITY PERCEPTIONS (FACTORS INFLUENCING RESIDENT PERCEPTIONS OF IMPACTS)

3.12 THEORETICAL FRAMEWORK FOR ASSESSING SOCIO-CULTURAL IMPACTS

3.13 THEORETICAL PERS PECTIVES: THEORIES AND MODELS 75

3.14 DOXEY'S INDEX OF IRRITATION (IRRIDEX) 75

3.15 BUTLER'S TOURIST AREA LIFE CYCLE MODEL 76

$\begin{array}{ll}3.16 \text { SOCIAL EXCHANGE THEORY } & 77\end{array}$

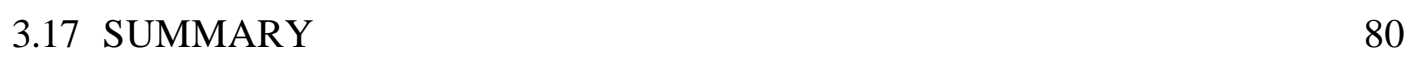

\section{CHAPTER 4: LITERATURE REVIEW: APPROPRIATE}

PLANNING FOR TOURISM IN DESTINATION COMMUNITIES

$\begin{array}{lll}4.1 & \text { INTRODUCTION } & 82\end{array}$

4.2 SOCIO-CULTURAL SUSTAINABILITY 82

4.3 THE NON-SUSTAINABLE DIMENSION OF CULTURAL TOURISM 4.3.1 Continuous use of cultural sites $\quad 83$

4.3.2 Lack of local control 83

4.3.3 Trivialisation or loss of authenticity 85

4.4 SUSTAINABLE DEVELOPMENT 85

4.5 SUSTAINABLE TOURISM 86 
4.6 CRITIQUE OF THE SUSTAINABLE TOURISM APPROACH 89

4.7 RESPONSIBLE TOURISM DEVELOPMENT 90

4.8 RESPONSIBLE COMMUNITY TOURISM AS THE WAY FORWARD? 92

4.9 TOWARDS A RESPONSIB LE COMMUNITY TOURISM APPROACH 93

4.10 WHY COMMUNITIES NEED TO BE EMPOWERED TO HAVE A MANAGEMENT ROLE 96

4.10.1 Economic empowerment 97

$\begin{array}{ll}4.10 .2 \text { Social empowerment } & 97\end{array}$

4.10.3 Psychological empowerment 98

4.10.4 Political empowerment 98

4.11 APPROPRIATE FORMS OF COMMUNITY TOURISM: ISSUES OF SCALE AND THE NATURE OF TOURISM DEVELOPMENT 99

4.12 HOW OUTSIDE VISITORS CAN MANAGE COMMUNITY TOURISM $\begin{array}{ll}\text { IMPACTS } & 101\end{array}$

$\begin{array}{ll}4.13 \text { SUMMARY } & 102\end{array}$

\section{CHAPTER 5: RESEARCH DESIGN AND METHODOLOGY}

$\begin{array}{lll}5.1 & \text { INTRODUCTION } & 104\end{array}$

5.2 OVERVIEW OF RESEARCH METHODOLOGIES IN THE SOCIAL $\begin{array}{ll}\text { SCIENCES } & 104\end{array}$

5.2.1 Qualitative approach 104

$\begin{array}{ll}\text { 5.2.2 Quantitative approach } & 106\end{array}$

5.3 TOWARDS TRIANGULATION AS AN APPROACH 107

5.4 METHODS OF DATA COLLECTION USED IN THE STUDY 111

5.4.1 Primary research methods for data collection 111

5.4.2 Secondary research methods for data collection 111

5.5 DESCRIPTION OF THE MAIN MEASUREMENT INSTRUMENT USED IN THE STUDY: THE LIKERT METHOD 111

5.5.1 Advantages of the Likert method 113

5.5.2 Construction of the Likert scale que stionnaire used in the study 113 
5.5.3 Pool of items (impact variables) derived from the literature and fieldwork

5.6 PROFILE OF RESPONDENTS

5.7 SAMPLING DESIGN AND SAMPLING METHODS USED IN THE STUDY

$\begin{array}{lll}\text { 5.7.1 Population and sampling frame } & 117\end{array}$

$\begin{array}{lll}5.7 .2 & \text { Sample size } & 118\end{array}$

5.7.3 Sampling technique followed for quantitative research design 118

5.8 DATA COLLECTION PROCEDURE (FIELDWORK) IN THE STUDY 120

5.9 DATA ANALYSIS OF LIKERT SCALE QUESTIONNAIRE 120

$\begin{array}{ll}\text { 5.9.1 The analysis of univa riate data used in the study } & 121\end{array}$

5.9.2 The analysis of bivariate data used in the study 122

5.9.3 The analysis of multivariate data used in the study 122

5.10 DESCRIPTION OF QUALITATIVE METHODOLOGY FOLLOWED 124

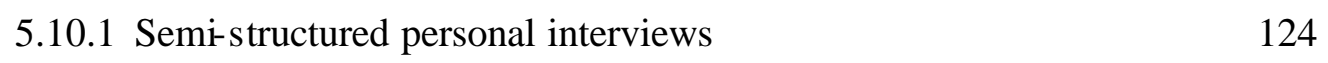

5.10.2 Participant observation $\quad 125$

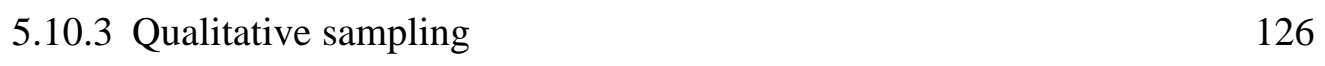

5.10.4 Sample size — qualitative study 126

5.10.5 Data analysis — qualitative study 126

$\begin{array}{ll}5.11 \text { VALIDITY OF DATA } & 128\end{array}$

$\begin{array}{ll}5.12 \text { RELIABILITY OF THE DATA } & 128\end{array}$

$\begin{array}{llr}5.13 \text { SUMMARY } & 129\end{array}$

\section{CHAPTER 6: PRESENTATION AND DISCUSSION OF RESULTS}

$\begin{array}{lll}6.1 & 130\end{array}$

6.2 GENERAL DEMOGRAPHIC INFORMATION 130

6.3 QUALITATIVE RESEARCH RESULTS

6.3.1 Results from semi-structured in-depth personal interviews 134

6.3.1.1 POSTIVE PERCEPTIONS 135

$\begin{array}{ll}\text { 6.3.1.2 NEGATIVE PERCEPTIONS } & 137\end{array}$ 


\subsubsection{INTERPRETATION OF REPORTED PERCEPTIONS}

6.3.2 Results derived from the researcher's field notes during participant observation

\subsection{QUANTITATIVE RESEARCH RESULTS}

6.4.1 Distribution of responses to socio-cultural impact statements

6.4.2 Responses to impact variables given by respondents who derive income from tourism and those who do not

6.4.3 The most positively perceived socio -cultural impacts 148

6.4.4 The most negatively perceived socio-cultural impacts

6.4.5 Difference in perceptions based on the demographic variable of income from tourism

6.4.6 Factor analysis

6.4.6.1 Results of factor analysis: direct principal component method using direct obliman method

6.4.6.2 Eigenvalues

6.4.6.3 Chronbach's alpha coefficient of reliability

6.4.7 Validity of scales and item analysis

6.4.8 ANOVA procedures (tests of analysis of variance)

6.4.8.1 ANOVA test: income from tourism

\section{CHAPTER 7: CONCLUSIONS AND RECOMMENDATIONS}

7.1 INTRODUCTION

7.2 REVIEW OF THE RESEARCH AIM AND OBJECTIVES OF THE STUDY

7.3 COMPREHENSIVE SUMMARY OF THE RESEACH AND MAIN FINDINGS

7.4 CONTRIBUTIONS OF THE PRESENT STUDY TO THE DISCIPLINE 
University of Pretoria etd - Ramchander, P (2004)

OF TOURISM MANAGEMENT 179

$\begin{array}{lll}7.5 & \text { SUGGESTIONS FOR FURTHER RESEARCH } & 180\end{array}$

7.6 THE CHALLENGE OF MANAGING RESPONSIBLE TOWNSHIP TOURISM IN SOWETO: TOWARDS A COMMUNITY APPROACH 182

7.7 GUIDELINES AND RECOMMENDATIONS FOR RESPONSIBLE TOWNSHIP TOURISM MANAGEMENT IN SOUTH AFRICA 187

7.8 SUMMARY

196

\section{REFERENCES}

199 


\section{SUMMARY}

Prior to the 1994 democratic elections, urban tourism in South Africa was strictly confined to so-called 'white' areas. Black townships, prevented from constituting an integral part of 'white' cities, were developed as dormitory towns, far removed from central business districts and white urban areas. Today post-apartheid Soweto, a conurbation of two million inhabitants with a rich political history, has come to symbolise the political freedom of the new South Africa. Since South Africa's first democratic elections in 1994 township tourism has been growing rapidly, with international tourists eager to see how the country has progressed. Motivated by an interest in the ethnic diversity and rich cultural heritage manifested in the daily lives and practices of township residents, tourists are visiting Soweto in increasing numbers.

Because cultural tourists are motivated by local cultures in choosing to visit a particular attraction, they have been identified as both a blessing and blight, as communities living in townships are affected both positively and negatively by township tourism. The socio cultural impacts of township tourism in South Africa, however, are not well documented. The purpose of the research undertaken was therefore to investigate the socio-cultural impacts of township tourism, as perceived by the host population, using Soweto as a case study. The purpose of this thesis is thus to present the findings of research conducted using a multiple-item Likert scale, in-depth interviews and participant observation as means for investigating host perceptions of socio-cultural impacts of township tourism in Soweto.

This study reveals that respondents were divided in their perceptions of the impacts of tourism on the host community. Those who received economic or employment benefits from tourism generally viewed its socio-cultural impacts positively. Conversely, others who did not receive these benefits claimed that the inequitable distribution of benefits from tourism has led to community friction, growing antipathy towards tourists and commodification of traditional culture. Blame is laid partially at the door of government who, it is claimed, has neither afforded residents the opportunity for participation in 
decision making relating to tourism planning and development in the township, nor offered the requisite funding or skills development support. A systematic analysis of tourism impacts can therefore help government planners, local decision-makers, tourism promoters and managers identify real concerns and issues in order for appropriate policies and action to be introduced.

The challenge of managing sustainable township tourism in South Africa, using a community approach, is discussed. Results from the study have the potential to provide the foundation on which to formulate principles or guidelines and recommend approaches to be applied in the development and management of sustainable township tourism in South Africa, so as to create the basis necessary for good practice for any community cultural tourism project. 


\section{ACKNOWLEDGEMENTS}

I wish to express my appreciation to the following people and organisations for their contributions to making this thesis possible:

? My promoter, Prof. Deon Wilson, of the Department of Tourism Management, University of Pretoria for his professional guidance and assistance.

? The National Research Foundation (NRF) for the scholarship awarded to me. Opinions expressed in this thesis and conclusions drawn are my own and must not be construed to be the opinions and conclusions of the NRF.

? Unisa for the bursaries and sabbatical leave granted for the completion of this study.

? All the fieldworkers and respondents in Soweto who participated in the qualitative and quantitative components of this study.

? Gauteng Tourism Authority (GTA), Johannesburg Tourism, SA Tourism, Jenny Briscoe (CEO of Gold Reef Guides), and the many tour guides and tour operators with whom I interacted for all their valuable assistance and time made available to me.

? Ms Elana Mauer of the University of Pretoria for the statistical analysis performed.

? Christo, for all your faith in my abilities. Your support during my studies has been of inestimable value.

? My family, especially my mother and my sister Rangila, for their continuous support and encouragement.

? Ms Janet Sheldon-Heeg of the Centre for Courseware Design and Development at Unisa for the language editing.

? Ms Filistea Naudé of the Gold Fields Library and Information Centre at Unisa Florida for her assistance with my literature search over the past four years.

? Ms Ingrid Booysen of the University of Pretoria and Ms Edmie Vosloo of the Centre for Courseware Design and Development at Unisa for cartographic and technical support.

? All my friends and colleagues from the Programme Group: Marketing and Tourism and the Directorate: Research at Unisa. 


\section{LIST OF APPENDICES}

$\begin{array}{lll}\text { APPENDIX A } & \text { Likert scale instrument } & 214\end{array}$

$\begin{array}{lll}\text { APPENDIX B } & \text { Definition of key terms } & 221\end{array}$

APPENDIX C Overall distribution of frequencies 232

APPENDIX D The means and standard deviation procedures 246

$\begin{array}{lll}\text { APPENDIX E } & \text { Results of factor analysis } & 251\end{array}$

$\begin{array}{lll}\text { APPENDIX F } & \text { Results of item analysis } & 260\end{array}$

$\begin{array}{lll}\text { APPENDIX G ANOVA procedures } & 270\end{array}$ 


\section{LIST OF TABLES}

TABLE 1.1 Research design: Towards the management of socio-cultural tourism impacts in Soweto

$\begin{array}{lll}\text { TABLE } 3.1 & \text { Interaction between tourists and hosts } & 61\end{array}$

TABLE 3.2 Key social aspects of tourism development 65

$\begin{array}{lll}\text { TABLE 3.3 Key social aspects of tourist-host interaction } & 67\end{array}$

TABLE 3.4 Key cultural impacts of tourism $\quad 68$

TABLE3.5 Causation theory of visitor-resident irritants - Doxey's Irridex 75

TABLE 4.1 Principles behind s ustainable tourism management 89

TABLE 4.2 Opportunities for host communities to be involved in the $\begin{array}{ll}\text { management of tourism } & 100\end{array}$

TABLE 5.1 Four categories with impact items generated from Likert Scale 115

TABLE 6.1 Section reference for quantitative and qualitative research results 130

$\begin{array}{lll}\text { TABLE 6.2 The most positively perceived attitude statements } & 148\end{array}$

$\begin{array}{lll}\text { TABLE 6.3 The most negatively perceived attitude statements } & 150\end{array}$

$\begin{array}{lll}\text { TABLE } 6.4 & \text { Factor loadings } & 156\end{array}$

$\begin{array}{lll}\text { TABLE 6.5 Factor correlation item analysis } & 163\end{array}$

$\begin{array}{lll}\text { TABLE 6.6 ANOVA test of income from tourism } & 165\end{array}$

$\begin{array}{lll}\text { TABLE } 6.7 & \text { ANOVA test of gender } & 167\end{array}$

$\begin{array}{lll}\text { TABLE } 6.8 & \text { ANOVA test of community attachment } & 168\end{array}$

TABLE 7.1 Review of research aim and objectives of the study 172 


\section{LIST OF FIGURES}

FIGURE 1.1 A multi-disciplinary perspective of tourism management

FIGURE 1.2 Key concepts pertinent to socio-cultural impacts of township

Tourism

FIGURE 2.1 Soweto Map

FIGURE 2.2 Soweto pictures of everyday life and historical landmarks

FIGURE 3.1 Tourism's socio-cultural impacts within the framework of wider social change

FIGURE 3.2 Butler's tourist area life cycle model 76

FIGURE 4.1 The cornerstones of sustainable development 86

FIGURE 4.2 The social dimension of sustainable tourism 88

FIGURE 5.1 Soweto study area indicating tourism hubs

FIGURE 6.1 The distribution of age groups of the 350 respondents Interviewed

FIGURE 6.2 Gender profile of respondents

FIGURE 6.3 Acquired educational level of respondents

FIGURE 6.4 Respondents deriving income from Soweto-based tourism

FIGURE 6.5 Distribution of monthly household income

FIGURE 6.6 Duration of residence in Soweto

$\begin{array}{lll}\text { FIGURE } 6.7 & \text { Responses to positive impact statements } & 145\end{array}$

$\begin{array}{lll}\text { FIGURE } 6.8 & \text { Responses to negative impact statements } & 146\end{array}$

$\begin{array}{lll}\text { FIGURE 6.9 The most positively perceived attitude statements } & 149\end{array}$

FIGURE 6.10 The most negatively perceived attitude statements 151

FIGURE 6.11 Difference in perception based on the demographic variable Income from tourism 